\title{
Zur Benachrichtigung
}

Die Atomgewichtskommission der Internationalen Union für Chemie veröffentlicht alljährlich die dem augenblicklichen Stande der Forschung entsprechenden Atomgewichtszahlen. Die vorliegende Auflage ist mit den für 1941 gültigøn Werten berechnet worden.

A. Thiel.

Man beachte die Vorbemerlkungen! 
